\title{
POST-COLLISIONAL MULTISTAGE MAGMATISM IN THE RIBEIRA MOBILE BELT: GEOCHEMICAL AND ISOTOPIC STUDY OF THE VÁRZEA ALEGRE INTRUSIVE COMPLEX, ESPÍRITO SANTO, BRAZIL
}

\section{SILVIA REGINA DE MEDEIROS ${ }^{1}$, CRISTINA MARIA WIEDEMANN-LEONARDOS ${ }^{2}$ AND JULIO CEZAR MENDES ${ }^{1}$}

\begin{abstract}
The Várzea Alegre Intrusive Complex (VAIC) corresponds to a post-collisional (late orogenic) pluton, related to the Brasiliano cycle, situated in the central part of the Espírito Santo State. It intrudes amphibolite to granulite facies metamorphic rocks of the Ribeira Belt. Two distinct domains were recognised in this zoned pluton: an inner domain with opx-gabbro, monzogabbro, diorite, quartz-diorite and megaporphyritic granite, and an outer one comprising an irregular and large ring of charnockitic rocks. Geochemical data from the former reveal medium to high-K calc-alkalic rocks, enriched in incompatible elements, mainly $\mathrm{Ba}, \mathrm{Sr}, \mathrm{La}, \mathrm{Ce}$ and $\mathrm{Pb}$ and partially depleted in $\mathrm{HFS}$ elements. The charnockitic rocks show a high-K alkali-calcic signature; they are rich in $\mathrm{Ba}, \mathrm{K}$ and some HFS elements, such as $\mathrm{Zr}$, $\mathrm{P}$ and Nb. The incompatible element enrichment detected in the rocks of the VAIC has been reported for several intrusions from this part of the Ribeira Belt. A Rb-Sr isochronic age of 508 \pm 12 Ma was determined for the megaporphyritic granite. The $\mathrm{T}_{\mathrm{DM}}$ model age varies from $1.3 \mathrm{Ga}$ (opx-gabbro) to ca. $1.67 \mathrm{Ga}$ (charnockitic rocks), which can be related to an important Mesoproterozoic crustal event. The calculated T $\mathrm{T}_{\mathrm{CH}}$ model ages of the cogenetic opx-gabbros and intermediary rocks is ca. $1.0 \mathrm{Ga}$, interpreted as the time when the basic magma was extracted from the source.
\end{abstract}

Keywords: post-collisional, high K calc-alkalic, multistage magmatism

INTRODUCTION The Espírito Santo State corresponds to the northern portion of the Ribeira Belt, which is the continuation of the Neoproterozoic Araçuaí orogen (Pedrosa-Soares and WiedemannLeonardos, subm.). In a late orogenic stage of the Brasiliano cycle (535 - $490 \mathrm{Ma}$ ), several complexly zoned plutons intrude the enclosing high-grade gneisses, highlighting the post-collisional magmatism of this region (Wiedemann et al. 997). The Várzea Alegre Intrusive Complex, located in the central part of Espírito Santo, is an example of this event. According to Pedrosa-Soares and Wiedemann-Leonardos (subm.), it is included in the G5 suite, which corresponds to the latest magmatic event of the orogen, and is characterized by several plutons with compositions varying from opx-gabbro to granite. This suite comprises meta-aluminous, high-K calc-alkaline, I-type granitoids originated in the lowermost continental crust with important mantle contributions. The VAIC has an outcropping area of $150 \mathrm{Km}^{2}$ and was studied by Mendes (1996). and Medeiros (1999). This paper presents the first Sm-Nd data of this type of magmatism in the Espírito Santo.

GEOLOGICAL AND PETROGRAPHIC ASPECTS The Várzea Alegre Complex corresponds to an inversely zoned pluton with an almost circular shape (Fig. 1). Its enclosing rocks are ortho and paragneisses of amphibolite to granulite metamorphic grade.

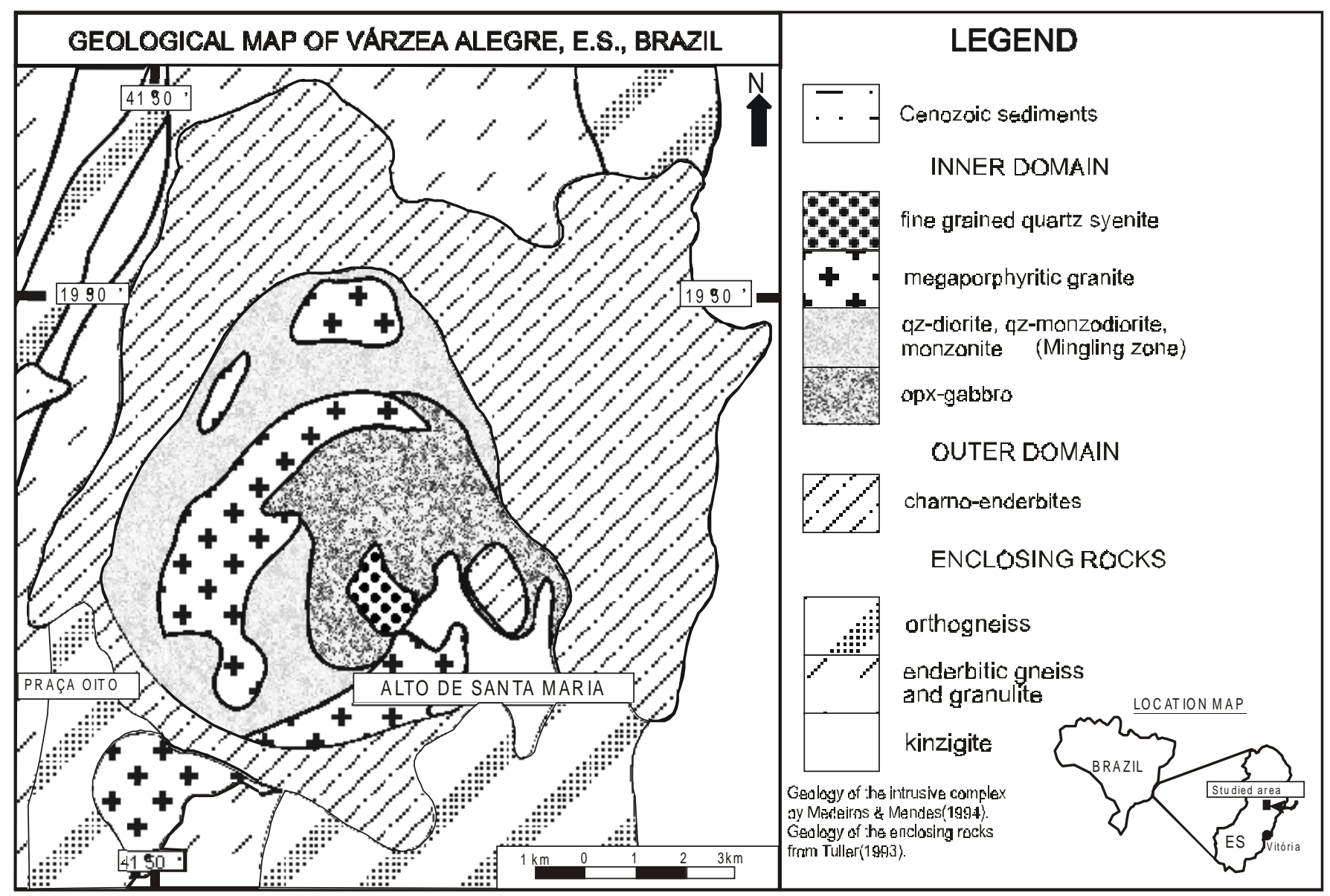

Figure 1 - Geological map of Várzea Alegre Intrusive Complex - ES

1- Department of Geology, IGEO/UFRJ, Cidade Universitária, Ilha do Fundão, 21949-900, Rio de Janeiro - RJ, Tel.: 055(021)598-9479, e-mail: medeiros@igeo.ufrj.br and julio@igeo.ufrj.br

2 - Institute of Geosciences, UnB , Campus Universitário - Asa Norte, 70910-900, Brasília - DF, Tel.: 055(061)-273-9193, e-mail: wiedeman@unb.br 
The intrusion has opx-gabbro/monzogabbro at the eroded center surrounded by diorite/quartz-diorite-monzodiorite and megaporphyritic granite. A small stock of sphene-bearing granite occurs close to the opx-gabbro (Medeiros 1999). The contact between the megaporphyritic granite and the diorite is a mingled/mixed zone, and the hybridization process (Medeiros et al.1996) probably produced quartz-diorite and quartz-monzodiorite.

The younger intrusion of Várzea Alegre is involved by a large, early emplaced, ring of dark green color and megaporphyritic charnockitic rocks. This outer domain varies in width from hundred meters, at the $\mathrm{S}$ and $\mathrm{W}$ borders, to almost $4 \mathrm{Km}$, at the $\mathrm{E}$ and $\mathrm{N}$ borders, forming expressive topography. Their mineralogy is made up of plagioclase $\left(\mathrm{An}_{32}\right.$ to $\left.\mathrm{An}_{40}\right)$, quartz, K-feldspar $\left(\mathrm{Or}_{89} \mathrm{Ab}_{11}\right.$ to $\left.\mathrm{Or}_{69} \mathrm{Ab}_{31}\right)$, biotite, hypersthene $\left(\mathrm{Wo}_{1.5-2,5} ; \mathrm{En}_{30-41} ; \mathrm{Fs}_{57-67}\right)$, calcic amphibole (Mg-hastingsitic hornblende and magnesian hastingsite), zircon, apatite, magnetite, ilmenite and pyrite (Mendes et al. 999).

The coarse-grained opx-gabbro and monzogabbro, showing intergranular to glomeroporphyritic and granular texture, contain more than $50 \%$ modal plagioclase $\left(\mathrm{An}_{40-60}\right)$. The hypersthene $\left(\mathrm{Wo}_{1-2} \mathrm{En}_{59-4}\right.$ $\left.\mathrm{Fs}_{40-52}\right)$ is the most common mafic phase, followed by biotite, salite augite $\left(\mathrm{Wo}_{48-46} \mathrm{En}_{41-35} \mathrm{Fs}_{11-19}\right)$, ilmenite and Ti-magnetite. The mafic minerals are frequently associated forming aggregates with apatite and zircon. The pyroxenes show evidence of subsolidus reactions, like exsolution lamellae, coronas of amphibole intergrowth with quartz and simplectites with opaque minerals. Curved, fractured and poligonized plagioclase and pyroxenes with kink bands are features of deformation in the opx-gabbro.

In the intermediary rocks, the mineralogical composition is oligoclase/andesine, amphibole (tchermackitic to Fe-pargasite), biotite, ferrihypersthene, salite, K-feldspar, ilmenite, magnetite, apatite and zircon. They show a subhedral inequigranular fabric, fine- to medium grained.

The megaporphyritic granite shows a coarse-grained matrix consisting of plagioclase $\left(\mathrm{An}_{24}\right)$, microcline, quartz, mesoperthite and biotite. Microcline as megacrystal is usually corroded, with abundant quartz, biotite and plagioclase inclusions. Zircon, sphene, epidote/ allanite and apatite are normally euhedral and tend to be concentrated in the biotite-rich domains, which surround the microcline megacrystals.

\section{GEOCHEMISTRY}

hypersthene-bearing ( quartz-diorites, granodiorites, quartzmonzodiorites and quartz-monzonites. They present medium to high incompatible elements-contents, including REE and HFS elements, such as $\mathrm{Zr}$ and $\mathrm{Nb}$, when compared to $\mathrm{N}$-Morb values. The REE patterns are fractionated and show small positive Eu anomalies. The chemical signature of the rocks is high-K calc-alkalic, and in the spidergrams they present negative $\mathrm{Ti}$ and $\mathrm{P}$ anomalies, suggesting an origin related to a subduction process (Fig. 2). Mendes (1996) and Mendes et al. (1997) geochemically distinguished two groups of rocks by means of incompatible versus compatible element diagrams. One of these groups evolved mainly by fractional crystallization of an intermediate magma and the other one by magma mixing, under anhydrous and reducing conditions. Geochemical modeling confirms this hypothesis. The mixing probably occurred after the partial melting of the lower crust, induced by underplating of a basaltic magma. The formation of such basaltic magma is probably related to partial melting of a previously enriched mantle source.

The geochemical behavior of the inner domain rocks indicates a large predominance of metaluminous, Hy-normative, silicaoversaturated lithotypes. When compared to N-MORB (Sun and McDonough 1989), they are enriched in $\mathrm{Ba}, \mathrm{Sr}, \mathrm{K}, \mathrm{La}$ and $\mathrm{Ce}$, and depleted in HFS elements ( $\mathrm{Ta}, \mathrm{Nb}, \mathrm{Zr}$, Hf and Ti). Anomalous values are not observed among the less incompatible elements (Fig. 2). Using the normalization values suggested by Pearce (1983), the pattern obtained for the incompatible element is similar to those of ocean islands calc-alkalic basalts. The whole major and trace element data (including REE) give a medium (basic/intermediate rocks) to high-K (megaporphyritic granite) calc-alkalic signature for the Várzea Alegre inner domain rocks. Two groups of rocks are clearly separated in the variation diagrams in Figure3: the basic to intermediate group (from opx-gabbro to quartz-monzodiorite) and the acidic group (granite). The compositional gap observed shows a lack of rocks in the $54 \%$ to $61 \% \mathrm{SiO}_{2}$ interval. The petrographic similarity and the differentiation trend in all diagrams indicate that the basic and intermediate lithotypes formed by differentiation. Their identical REE and incompatible element patterns confirm a genetic link between them (Figures 1 and 3 ). The granitic rocks have different mineralogy and chemical signature. They define a different trend and their REE and incompatible elements patterns are quite distinct (Fig. 4).

The REE quantities of the inner domain rocks are high, mainly the LREE. The granite is different from the others in that it has a negative Eu anomaly and slightly more fractionated patterns. The patterns of the basic and intermediate rocks resemble those of basanites and magmatites from the anomalous portion of the mid-ocean ridge, related to an enriched mantle, E-MORB type (Frey 1984). Such geochemical signatures are also reported by Ludka et al. (1998) for many intrusive rocks of the Ribeira Belt.

The $\mathrm{SiO}_{2}$-contents of the charnockitic rocks range from $54 \%$ to $65 \%$ (Fig. 3). In spite of this silica interval be partially coincident with the gap observed between the granites and basic/intermediate rocks from the inner domain, they probably do not have cogenetic relation. The general geochemical behavior of the inner domain lithotypes and charnockitic rocks differ considerably in the $\mathrm{TiO}_{2}, \mathrm{Fe}_{2} \mathrm{O}_{3}, \mathrm{CaO}, \mathrm{K}_{2} \mathrm{O}$, $\mathrm{Sr}, \mathrm{Ba}, \mathrm{Nb}$ and $\mathrm{Zr}$-contents. Also, the distinct patterns revealed by the incompatible elements and REE diagrams (Figures 2 and 4), besides the lower whole rock \#Mg of the charnockites (strong reducing conditions) can be still used as evidence of different magma sources for the inner and outer domain rocks of VAIC.

ISOTOPIC DATA $\mathrm{Rb}-\mathrm{Sr}$ and $\mathrm{Sm}-\mathrm{Nd}$ isotopic analyses were carried out at the Laboratory of Geochronology at the Institute of Geosciences of the University of São Paulo (IG-USP). Seventeen samples were dosed for Rb-Sr determination: 2 opx-gabbros, 2 quartzdiorites, 1 quartz-monzonite, 6 megaporphyritic granite and 6 charnockites (Table 1). Sm-Nd data were obtained for 7 samples selected from those already dosed for $\mathrm{Rb}-\mathrm{Sr}$ (Table 2). The $\mathrm{Rb}-\mathrm{Sr}$ data made possible the attainment of an isochron only for the
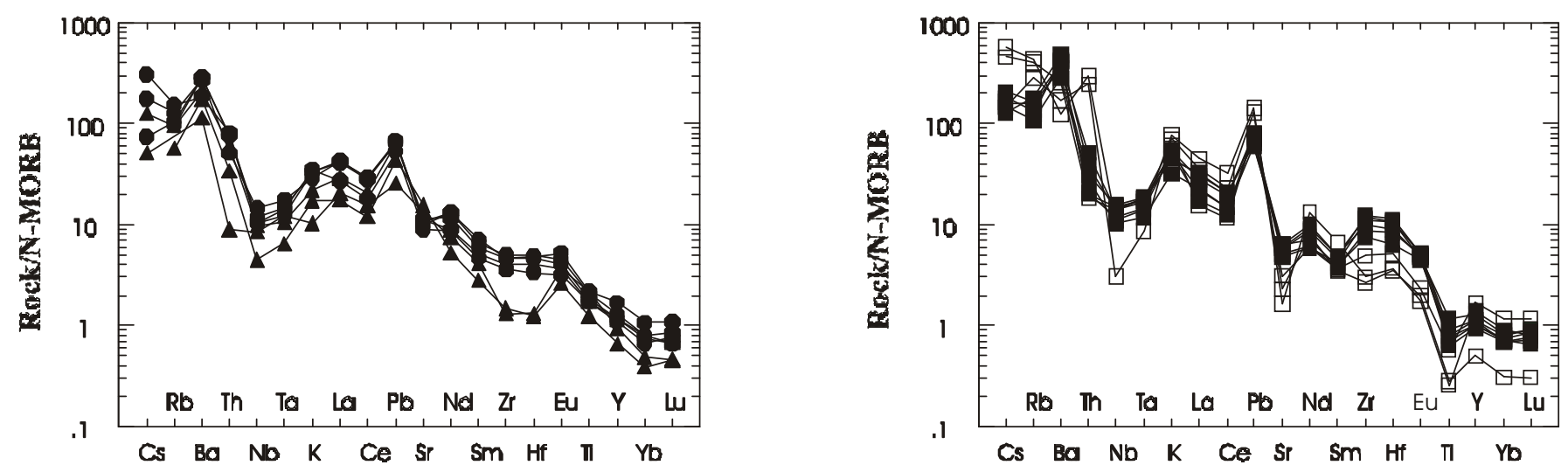

Figure 2 - N-MORB-normalized (Sun and McDonough 989) spidergram for the rocks of VAIC. Symbols: (s) opx-gabbro, monzogabbro; (l) dioritelquartz-diorite, quartz-monzodiorite; $(n)$ megaporphyritic granite; $(\bullet)$ charnockitic rocks. 

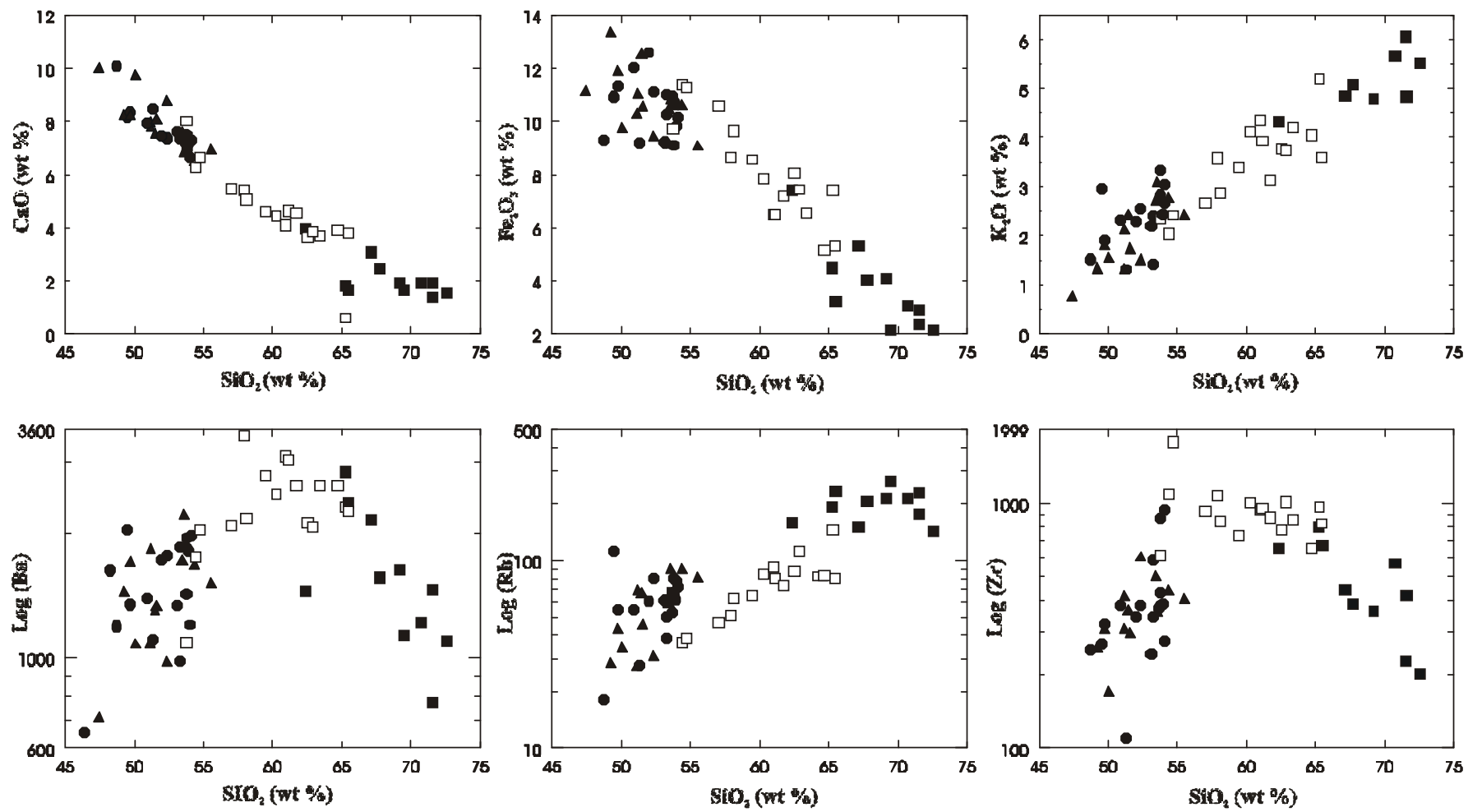

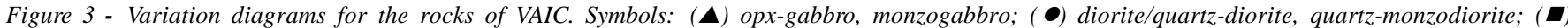
megaporphyritic granite; $(\square)$ charnockitic rocks.
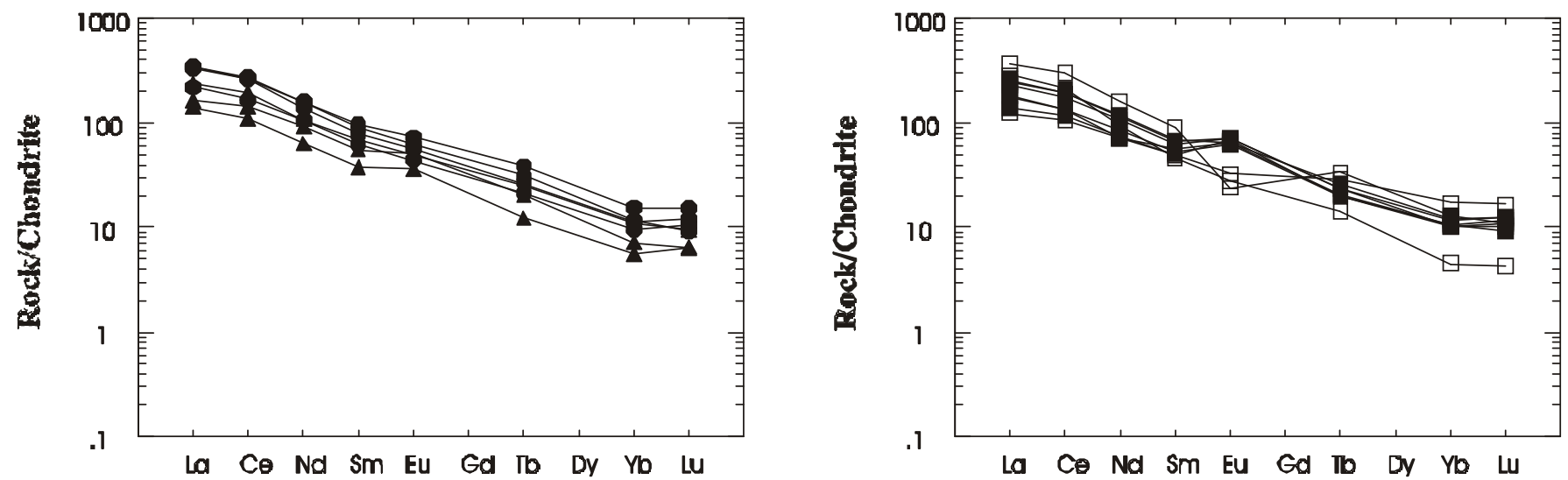

Figure 4 - Chondrite-normalized (Boynton 984) REE-spectra (or patterns) for the rocks of VAIC. Symbols: ( $\mathbf{\Delta})$ opx-gabbro, monzogabbro; ( $\bullet$ ) dioritelquartzdiorite, quartz-monzodiorite; $(\boldsymbol{\square})$ megaporphyritic granite; $(\square)$ charnockitic rocks.

Table 1 - Rb-Sr isotopic selected results for the rocks of the VAIC

\begin{tabular}{|c|c|c|c|c|c|c|c|c|c|}
\hline Rocks types & $\begin{array}{c}\mathbf{R b} \\
(\mathbf{p p m})\end{array}$ & $\begin{array}{c}\mathrm{Sr} \\
(\mathrm{ppm})\end{array}$ & ${ }^{87} \mathrm{Rb} /{ }^{86} \mathrm{Sr}$ & Erro & ${ }^{87} \mathrm{Sr} /{ }^{86} \mathrm{Sr}^{(f)}$ & Erro & ${ }^{87} \mathrm{Sr} /{ }^{86} \mathrm{Sr}^{(i)}$ & $\varepsilon_{\mathrm{Sr}}^{(\mathbf{0})}$ & $\varepsilon_{0,55 \mathrm{GaSr}}$ \\
\hline Quartz-diorite & 65.92 & 952.40 & 0.1995 & 0.0028 & 0.708690 & 0.000130 & 0.707126 & - & - \\
\hline Quartz-diorite & 53.24 & 955.61 & 0.1613 & 0.0024 & 0.708330 & 0.000080 & 0.707065 & 47.23 & 45.66 \\
\hline Quartz-monzonite & 50.79 & 1300.86 & 0.1130 & 0.0018 & 0.707420 & 0.000130 & 0.706534 & 34.32 & 38.12 \\
\hline Opx-gabbro & 15.71 & 1033.81 & 0.0440 & 0.0006 & 0.707610 & 0.000080 & 0.707265 & 37.02 & 48.50 \\
\hline Opx-gabbro & 34.52 & 1108.48 & 0.0901 & 0.0013 & 0.707120 & 0.000130 & 0.706414 & 30.07 & 36.41 \\
\hline Granite & 204.20 & 182.60 & 3.2440 & 0.0920 & 0.731560 & 0.000160 & 0.706125 & - & 32.31 \\
\hline Granite & 242.20 & 155.30 & 4.5280 & 0.1280 & 0.740730 & 0.000110 & 0.705228 & - & 19.56 \\
\hline Granite & 159.60 & 365.60 & 1.2650 & 0.0360 & 0.717530 & 0.000060 & 0.707612 & - & 53.43 \\
\hline Charnockite & 109.80 & 666.20 & 0.4770 & 0.0130 & 0.715390 & 0.000190 & 0.711650 & 147.37 & 110.80 \\
\hline Charnockite & 59.79 & 665.12 & 0.2602 & 0.0037 & 0.710740 & 0.000160 & 0.708700 & 81.41 & 68.89 \\
\hline Charnockite & 75.61 & 674.14 & 0.3262 & 0.0050 & 0.711980 & 0.000120 & 0.709422 & 99.01 & 79.15 \\
\hline
\end{tabular}


Table 2 - Sm-Nd isotopic results for the rocks of the VAIC

\begin{tabular}{|c|c|c|c|c|c|c|c|c|c|}
\hline Rock types & $\begin{array}{c}\mathrm{Sm} \\
(\mathrm{ppm})\end{array}$ & $\begin{array}{c}\mathrm{Nd} \\
(\mathrm{ppm})\end{array}$ & $\begin{array}{l}{ }^{147} \mathrm{Sm} /{ }^{144} \mathrm{Nd} \\
\text { (error) }\end{array}$ & $\begin{array}{l}{ }^{143} \mathrm{Nd} /{ }^{144} \mathrm{Nd} \\
\text { (error) }\end{array}$ & ${ }^{143} \mathrm{Nd} /{ }^{144} \mathrm{Nd}^{(1)}$ & $\varepsilon_{\mathrm{Nd}}^{(0)}$ & $\varepsilon_{0,55 \mathrm{GaNd}}$ & $\begin{array}{l}\mathrm{T}_{\mathrm{DM}} \\
(\mathrm{Ga})\end{array}$ & $\begin{array}{l}\mathrm{T}_{\text {chur }} \\
(\mathrm{Ga})\end{array}$ \\
\hline Quartz-monzonite & 16.203 & 98.014 & $0.099963(315)$ & $0.511902(41)$ & 0.511542 & -14.36 & -7.56 & 1.528 & 1.14 \\
\hline Quartz-diorite & 17.071 & 100.657 & $0.102553(343)$ & $0.511925(37)$ & 0.511555 & -13.91 & -7.31 & 1.532 & 1.15 \\
\hline Opx-gabbro & 6.866 & 41.867 & $0.099795(71)$ & $0.512047(28)$ & 0.511687 & -11.53 & -4.73 & 1.329 & 0.93 \\
\hline Opx-gabbro & 11.477 & 70.094 & $0.099633(84)$ & $0.512002(24)$ & 0.511643 & -12.41 & -5.59 & 1.383 & 0.99 \\
\hline Charnockite & 15.694 & 87.247 & $0.108774(343)$ & $0.511889(37)$ & 0.511497 & -14.61 & -8.44 & 1.675 & 1.29 \\
\hline Charnockite & 12.433 & 70.400 & $0.106796(336)$ & $0.511971(34)$ & 0.511586 & -13.01 & -6.70 & 1.527 & 1.13 \\
\hline Charnockite & 15.707 & 95.212 & $0.099754(319)$ & $0.511955(39)$ & 0.511596 & -13.32 & -6.51 & 1.455 & 1.07 \\
\hline
\end{tabular}

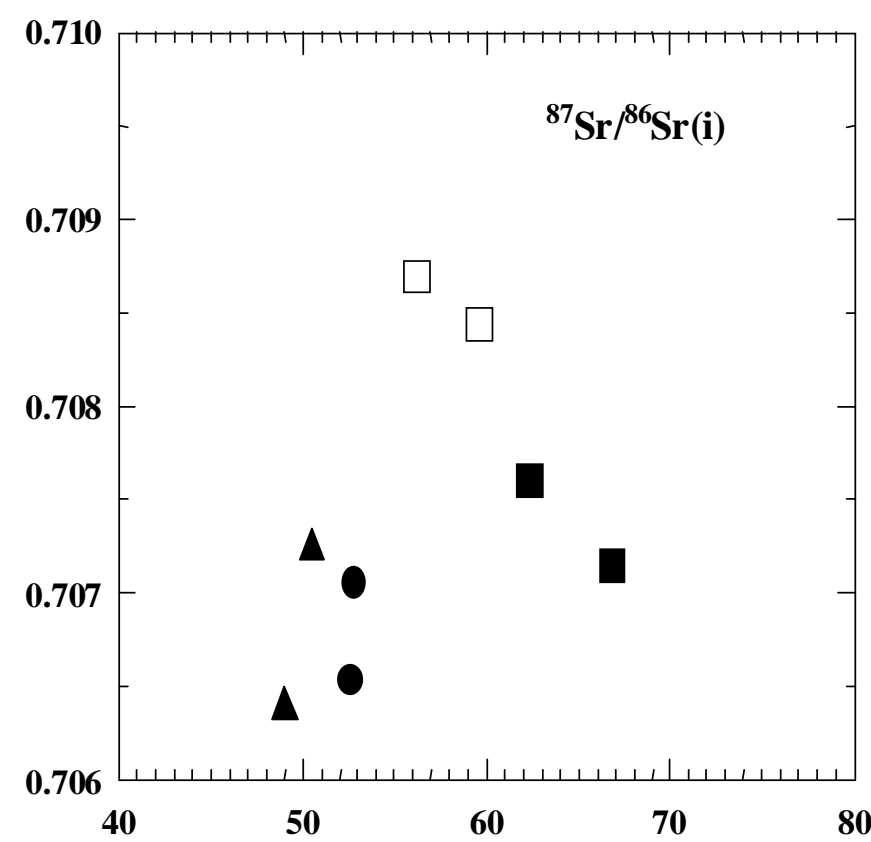

\section{$\mathrm{SiO}_{2}$}

Figure $5-\mathrm{SiO}_{2} x$ initial ${ }^{87} \mathrm{Sr}{ }^{86} \mathrm{Sr}$ for the rocks of Várzea Alegre Intrusive

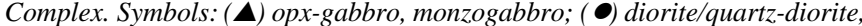
quartz-monzodiorite; ( $\boldsymbol{( \boldsymbol { D } )}$ megaporphyritic granite; $(\square)$ charnockitic rocks.

megaporphyritic granite, which yield an age of $508 \pm 12 \mathrm{Ma} .\left({ }^{87} \mathrm{Sr} /{ }^{86} \mathrm{Sr}\right.$ initial ratio of 0.7084$)$. Similar ages $\left(513 \mathrm{Ma},{ }^{87} \mathrm{Sr}^{86} \mathrm{Sr}_{\mathrm{i}}=0.7072\right)$ were obtained by Söllner et al. (1991) for calc-alkalic post-collisional intrusions from southern Espírito Santo, such as Santa Angélica, Iconha and Mimoso do Sul. A previously assumed crustal contribution for this granite is confirmed by the calculated initial ${ }^{87} \mathrm{Sr} /{ }^{86} \mathrm{Sr}$ ratio.

$\mathrm{The}{ }^{87} \mathrm{Sr} /{ }^{86} \mathrm{Sr}$ initial ratios, calculated for an age of $550 \mathrm{Ma}$, plotted against $\mathrm{SiO}_{2}$ (Fig. 5) plainly separate the basic/intermediate lithotypes, the granites and the charnockitic rocks, which show the highest $\mathrm{Sr}$ radiogenic and $\mathrm{e} 550 \mathrm{Sr}$ values.

The $\mathrm{T}_{\mathrm{DM}}$ model age vary from $1.3 \mathrm{Ga}$ (opx-gabbros) to $1.5 \mathrm{Ga}$ (charnockitic rocks). The calculated $\varepsilon N d(t)$ range from ca. -5.0 (opxgabbros) to ca. -7.3 (intermediary rocks), and it is ca. -6.5 for the charnockitic rocks. The $\mathrm{T}_{\mathrm{DM}}$ age versus $\varepsilon \mathrm{Nd}(\mathrm{t})$ values represented as lines in the diagram of the Figure 6 exhibit a model $\mathrm{Nd}$ isotope evolution for the rocks of VAIC. Janasi et al. (1997) obtained similar Mesoproterozoic ages interval for syn-collisional calc-alkaline granitoids from São Paulo and Minas Gerais. They interpreted the results as an important crust-forming event for the area, possible in a subduction environment with lithospheric mantle metassomatism.

The calculated $\mathrm{T}_{\mathrm{CHUR}}$ model ages for the cogenetic basic and intermediary rocks are around $1.0 \mathrm{Ga}$. This age is considered more appropriate for the extraction of the parental magma from the mantle, having in mind the enriched geochemical signature of the rocks here studied.

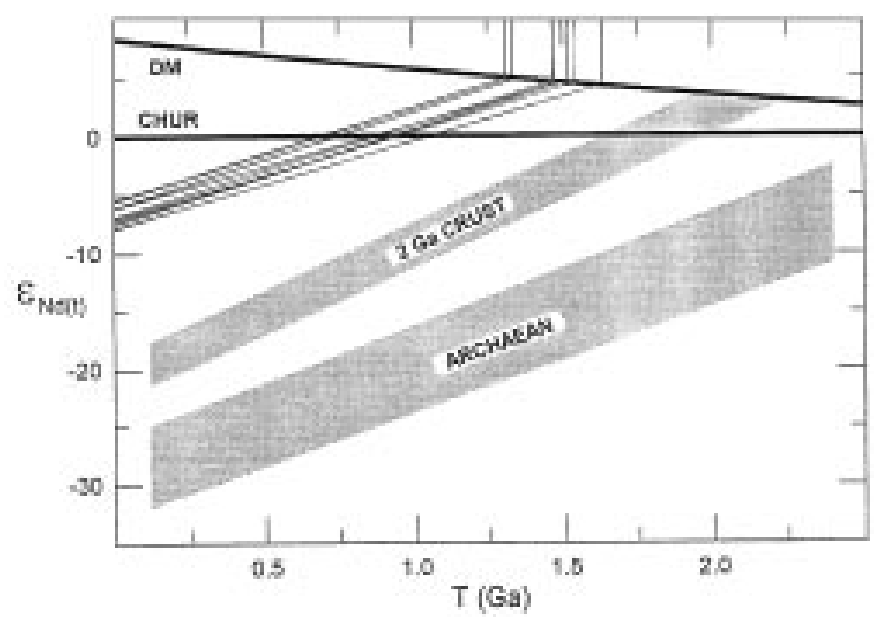

Figure 6 - $\varepsilon N d$ vs. $T(\mathrm{Ga})$ diagram showing model Nd isotope evolution for the rocks of VAIC (after De Paolo 988).

DISCUSSION AND CONCLUSIONS The obtained Rb-Sr isochron for the megaporphyritic granite $(508 \pm 12 \mathrm{Ma})$ reflects a crystallization age and confirms the post-collisional emplacement of the inner domain. Field relationships point to an early emplacement of the charnockitic outer shell. U-Pb in zircon yielded crystallization age of 535-520 Ma (Bilal et al. 1998) for the same charnockitic suite from the neighboring Ibituba and Itapina massifs, supporting our field inference. The highest Sm-Nd model age $\left(\mathrm{T}_{\mathrm{PM}}\right)$ and $\varepsilon \mathrm{Nd}(\mathrm{t})$ values for the intermediary lithotypes, when compared to the opx-gabbro, must imply mixing ages once they are geochemically cogenetic. The $\varepsilon \mathrm{Nd}(\mathrm{t})$ of -6.5 and $8550 \mathrm{Sr}$ of 79-110 for the charnockitic rocks corroborate the proposal of Mendes et al. (1997) who suggested a partial melt of the lower crust induced by an underplating of an enriched basic magma, which was irregularly mixed with the crustal component. The behavior of some incompatible/HFS elements supports this mantle contribution.

Sm-Nd CHUR model age of around $1.0 \mathrm{Ga}$ was calculated for the gabbro and intermediate cogenetic rocks. This age is related to the time when the basic magma was extracted from the mantle, and is here considered as having an important geological significance due to chemical enrichment already mentioned. Another interpretation for this age could be its relation with an episode of mantle enrichment. This episode can be associated to a continental rift phase in the northern part of the Araçuaí Belt, in response to the rising of a mantelic plume (Correa-Gomes and Oliveira 997, Martins-Neto 1998b), and recorded by basic dyke swarm, that yielded ages from ca. 1.05 to $0.9 \mathrm{Ga}-\mathrm{U} / \mathrm{Pb}$ in zircon (Machado et al. 989).

This multistage magmatism records a progressive increase in the amount of mantelic melts mixed with different crustal melts, from around 530 to $490 \mathrm{Ma}$, suggesting an important mechanism of underplating and crustal delamination during the collapse of the orogen.

Acknowledgements To CNPq and PADCT for financial support, Roberto Weinberg for his comments and valuable suggestions, and to two anonymous referees of RBG for the critical review of the manuscript. 


\section{References}

Bilal E., Nalini Jr. H.A., Horn H., Correa-Neves J.M., Giret A., Fuzikawa K., Fernandes M. L. Mello F., Moutte J. 1998 Neoproterozoic Granitoid suites of Rio Doce Region, Brazil. In: International Conference on Basement Tectonics, $14^{\text {th }}$, Ouro Preto, Abstracts: $41-43$

Boynton W.V. 1984. Cosmochemistry of the rare earth element: meteorite studies. In: Henderson P. ed. Rare Earth Element Geochemistry. Amsterdan. Elsevier, 63-114.

Correa-Gomes L.C. and Oliveira E. P. 1997. O enxame radial gigante de diques máficos da província Bahia-Congo: implicações reológicas e tectônicas da presença de uma pluma mantélica na interface América do Sul-África, 1,0 Ga atrás. In: SBG, Simp. Nac. Estudos Tectônicos, 6, Pirenópolis, Anais: 52-55.

De Paolo, D.P. 1988. Neodymium isotope geochemistry. An introduction. Springer-Verlag, $187 \mathrm{p}$.

Frey F.A. 1984. Rare earth element abundances in upper mantle rocks. In: Henderson, P. ed. Rare Earth Element Geochemistry. Amsterdan, Elsevier, 63-114.

Janasi V.A., Haddad R.C., Vlach, S.R.F. 1997. Comments on the Sm-Nd isotope systematics of calc-alkaline granitoids from Pinhal-Ipiúna batholith (São Paulo and Minas Gerais, Brazil). In: South Am. Symposium on Isotope Geology, Campos do Jordão. Extend. Abstract, 147-150.

Ludka I.P., Wiedemann C.M., Töpfner C. 1998. On the origin of incompatible elemen enrichment in the Venda Nova pluton, Espírito Santo, southeast Brazil. J. South Am. Earth Sc., 11:473-486.

Machado N., Schrank A., Abreu F.N., Knauer L.G., Almeida-Abreu P.A. 1989. Resultado preliminares da geocronologia U-Pb na Serra do Espinhaco Meridional. Boletim da Sociedade Brasileira - Núcleo Minas Gerais, 10:171-174.

Martins-Neto M.A. 1998. Mantle plume, rifting and the early Noeproterozoic glaciation in the São Francisco craton and Araçuá belt, southeastern Brazil. In: International Conference on Basement Tectonics, $14^{\text {th }}$, Ouro Preto, Abstracts, p. 32-34.

Medeiros S.R., Mendes J.C., Wiedemann C.M. 1994. Feições diagnosticas do complexo intrusivo de Várzea Alegre, ES. In: SBG, Cong. Bras. Geol., 38, Camboriú, Bol. Res. Exp, 1:140-141.

Medeiros S.R., Wiedemann C.M., Vriend S. 1996. Evidências de Campo e Petrográficas de Processos de Mingling no Complexo Intrusivo de Várzea Alegre - ES. In: SBG, Cong. Bras. Geol., 39, Salvador, Anais, 2:127.
Medeiros S.R. 1999. Estudo Mineralógico, Petrográfico, Geoquímico e Isotópico do Complexo Intrusivo de Várzea Alegre - ES. Instituto de Geociências, Universidade $\mathrm{Fe}-$ deral do Rio de Janeiro, PhD Thesis, 174p.

Medeiros S. R., Wiedemann C. M., Vriend S. (subm.). Evidence of mingling between contrasting magmas in a deep plutonic environment: the example of Várzea Alegre, in the Ribeira Mobile Belt, Esp. Santo, Brazil. An. Acad. Bras. Ci. (subm.)

Mendes J.C, McReath I., Wiedemann C., Figueiredo M.C.H. 1997. Charnockitóides do Maciço de Várzea Alegre: um novo exemplo do magmatismo cálcio-alcalino de altoK no arco magmático do Esp.Santo. Rev. Bras. Geoc. 27:13-24.

Mendes J.C., Wiedemann C., McReath I. 1999. Charnockitic magmatic rocks from the Várzea Alegre Massif, Espírito Santo, Southeast Brazil: conditions of formation. Rev.Bras. Geoc. 29.

Mendes J.C. 1996. Caracterização petrogenética das bordas noríticas e charnoquitóides dos maciços de Venda Nova e Várzea Alegre - ES. IGEO/USP, $\mathrm{PhD}$ Thesis, $238 \mathrm{p}$.

Pedrosa-Soares A.C. and Wiedemann-Leonardos C M. (subm.). Evolution of the Araçua Belt and its connection to the Ribeira Belt, Eastern Brazil. In: Cordani, U. (ed.) Geotectonic Evolution of South America.

Pearce J.A. 1983. Role of the sub-continental lithosphere in magma genesis at active continental margins. In: Hawkesworth, C.J. \& Norry, M.J. (eds.) Continental basalts and mantle xenoliths. Shiva, Nantwich, 230-249.

Söllner F., Lammerer B., Weber-Diefenbach K. 1991. Die Krustenentwicklung in de Küstenregion nördlich von Rio de Janeiro/Brasilien. Münchner Geologische Hefte, 4, 100p.

Sun S.S. and McDonough W.F. 1989. Chemical and isotopic systematic of oceanic basalts: implications for mantle composition and processes. In: Magmatism in the Ocean Basins. Geol. Soc. Sp. Pub., 42:313-345.

Wiedemann C. M., Mendes J.C., Moura J.C., Costa Nascimento R.C., Ludka I.P. 1997. Granitoids of the Espírito Santo Magmatic Arc. In: Int. Symp. Granites and Associated Mineralizations $2^{\text {nd }}$ - Excursion Guide, Salvador, 57-76.

Contribution IGC-063

Received February 15, 2000 Accepted for publication May 4,2000 